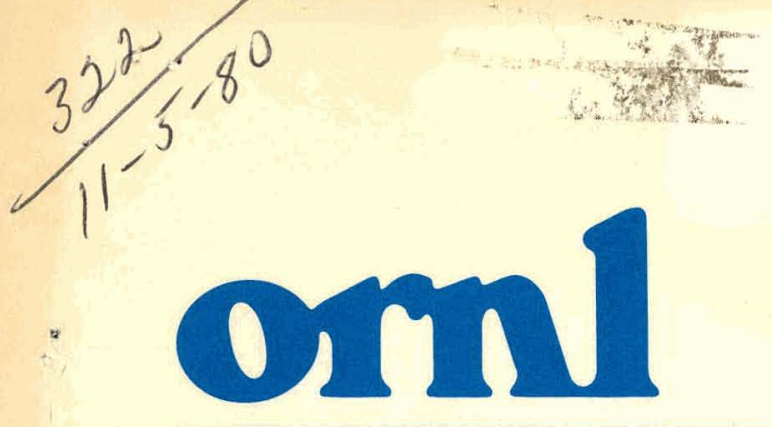

OAK

RIDGE

NATIONAL

LABORATORY

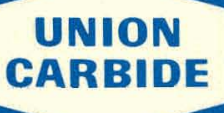

\section{Rheology of Sludge-Slurry Grouts}

Earl W. McDaniel
OPERATED BY

UNION CARBIDE CORPORATION FOR THE UNITED STATES DEPARTMENT OF ENERGY 


\section{DISCLAIMER}

This report was prepared as an account of work sponsored by an agency of the United States Government. Neither the United States Government nor any agency Thereof, nor any of their employees, makes any warranty, express or implied, or assumes any legal liability or responsibility for the accuracy, completeness, or usefulness of any information, apparatus, product, or process disclosed, or represents that its use would not infringe privately owned rights. Reference herein to any specific commercial product, process, or service by trade name, trademark, manufacturer, or otherwise does not necessarily constitute or imply its endorsement, recommendation, or favoring by the United States Government or any agency thereof. The views and opinions of authors expressed herein do not necessarily state or reflect those of the United States Government or any agency thereof. 


\section{DISCLAIMER}

Portions of this document may be illegible in electronic image products. Images are produced from the best available original document. 


\section{Printed in the United States of America. Available from National Technical Information Service \\ U.S. Department of Commerce \\ 5285 Port Royal Road, Springfield, Virginia 22161 \\ NTIS price codes-Printed Copy: A03; Microfiche A01}

This report was prepared as an account of work sponsored by an agency of the United States Government. Neither the United States Government nor any agency thereof, nor any of their employees, makes any warranty, express or implied, or assumes any legal liability or responsibility for the accuracy, completeness, or usefulness of any information, apparatus, product, or process disclosed, or represents that its use would not infringe privately owned rights. Reference herein to any specific commercial product, process, or service by trade name, trademark, manufacturer, or otherwise, does not necessarily constitute or imply its endorsement, recommendation, or favoring by the United States Government or any agency thereof. The views and opinions of authors expressed herein do not necessarily state or reflect those of the United States Government or any agency therenf. 
Contract No. W-7405-eng-26

CHEMICAL TECHNOLOGY DIVISION

NUCLEAR FUEL AND WASTE PROGRAMS

Hydrofracture Mix Development Studies

(Act1vity No. AR $051005 \mathrm{~K} ; 189$ No. ONL-WNO5)

RHEOLOGY OF SLUDGE-SLURRY GROUTS

Earl W. MçDaniel

Date Pub1ished - October 1980

NOTICE This document contains information of a preliminary nature.

It is subject to revision or correction and therefore does not represent a final report.

\author{
OAK RIDGE NATIUNAL LABORATORY \\ Oak Ridge, Tennessee 37830 \\ operated by \\ UNION CARBIDE CORPORATION \\ for the \\ DEPARTMENT OF ENERGY
}




\section{THIS PAGE}

\section{WAS INTENTIONALLY}

LEFT BLANK 


\section{CONTENTS}

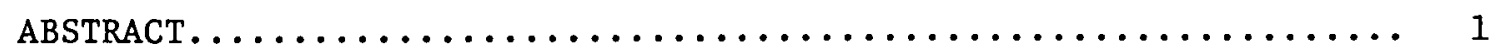

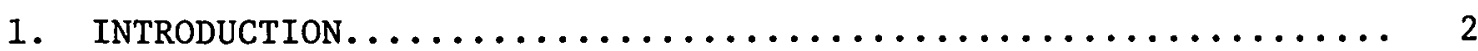

2. BASIC CONCEPTS............................... 2

2.1 Puwer Law Model............................ 5

3. EXPERIMENT AND RESULTS........................... 6

3.1 Determination of Flow Property Reference Points........ 6

3.2 Equipment and Mixing.......................... 8

3.3 Slurries................................. 9

3.4 Sludge-Slurry Grouts....................... 10

3.5 Effect of $\mathrm{pH}$ on Sludge-Slurry Vicosity............. 13

3.6 The Use of Chemical Additives to Control Flow Properties of Sludge-Slurries and Cementitious Grouts.......... 13

4. CONCLUSIONS AND RECOMMENDATIONS $\ldots \ldots \ldots \ldots \ldots \ldots \ldots \ldots \ldots, 20$

5. ACKNOWLEDGMENTS............................. 21

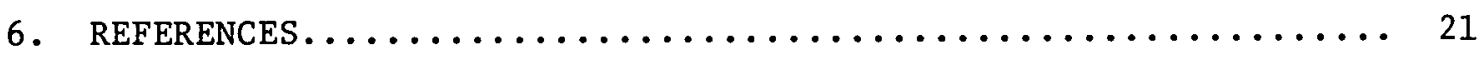




\section{RHEOLOGY OF SLUDGE-SLURRY GROUTS}

Earl W. McDanie1

\section{ABSTRACT}

A series of rheograms was developed that relates the critical velocity (velocity where flow changes from laminar to turbulent) of a cementitious grout that incorporates a suspended sludge-slurry to the critical velocity of a reference grout made with a simulated waste solution.

The sludge that is now in the Gunite waste tanks at the Oak Ridge National Laboratory (ORNL) will be suspended and pumped to the new waste storage tanks in Melton Valley. The sludge will then be blended with a cement mix base to form a grout which will be injected underground by the shale fracturing process. This report describes the materials, equipment, and techniques used in the laboratory studies to suspend sludges and mix sludge-slurry grouts that have flow properties similar to those of current shale fracturing grouts.

Bentonite clay is an effective suspender in dilute $\mathrm{NaNO}_{3}$ solutions: 15 wt \% solids can be suspended with 2.0 wt \% bentonite in a $0.1 \mathrm{M} \mathrm{NaNO}_{3}$ solution. Other suspending materials were evaluated, but bentonite gave the best results.

If a slurry grout heromes ton viscous to pump, methods must be available to "thin" the mixture. A number of thinners, friction reducers, and plasticizers were examined. Q-Broxin,* a thinner supplied by Baroid, reduced the velocity of a grout required for turbulent flow in a $5.0-\mathrm{cm}$ (2-in.)-diam tube from 1.76 to $1.20 \mathrm{~m} / \mathrm{s}(5.79$ to $3.95 \mathrm{ft} / \mathrm{s})$; FX-32C,** a plasticizer supplied by Fox Industries, Inc., reduced the velocity from 1.76 to $0.75 \mathrm{~m} / \mathrm{s}(5.6$ to 2.45 $\mathrm{ft} / \mathrm{s})$.

\footnotetext{
*Manufactured by Baroid Petroleum Services, Houston, Tex. *** Manufactured by Fox Industries, Inc., Baltimore, Md.
} 


\section{INTRODUCTION}

The sludge that is now in the Gunite waste tanks at ORNL will be suspended and pumped to the new intermediate-level waste (ILW) storage tanks in Melton Valley. Subsequently, this suspended sludge will be pumped to the new shale fracturing facility and combined with a cement mix base to form a grout. This grout will then be injected underground by the shale fracturing technique (Fig. 1). The grout containing the slurry must have properties similar to those of the current shale fracturing grouts. 1 It must be fluid and remain fluld for al ledsl $24 \mathrm{~h}$, ex hibit phase separation of $<5 \%$, and have an acceptable compressive strength and leach rate.

Experiments were conducted to determine the critical velocity (the velocity at which flow changes from laminar to turbulent) for a standard dry-solids blend and a simulated waste solution.1,2 This point was uscd as a reference for the flow characteristics of more viscous sludge-slurries, which would require less dry-solids addition to yield the same critical velocity as that of the reference mix.

Various materials were evaluated as suspending agents for the sludge. Data are presented on the use of chemical additives to control the flow properties of sludge-siurriess and cemenliliuus grouts. Mcthode have been developed to estimate and control the flow properties of sludge-slurry grout during a shale-fracturing waste disposal operation.

This report describes the develupmelll uf a serieg of rhcograms that relates the flow characteristics of a grout in whlch past pumping expcrience is available to a grout made with a sludge-slurry for which no pumping data is available. This was accomplished by establishing rheological reference points.

\section{BASTC CONCFPTS}

The flow characteristics of fluids are conventionally classified as Newtonian or non-Newtonian. Newtonian fluids such as oil or water exhibit a direct and constant proportionality between shear rate and shear stress. In a fluid of this type, viscosity is independent of the shear rate at 
ORNL DWG 80-973R

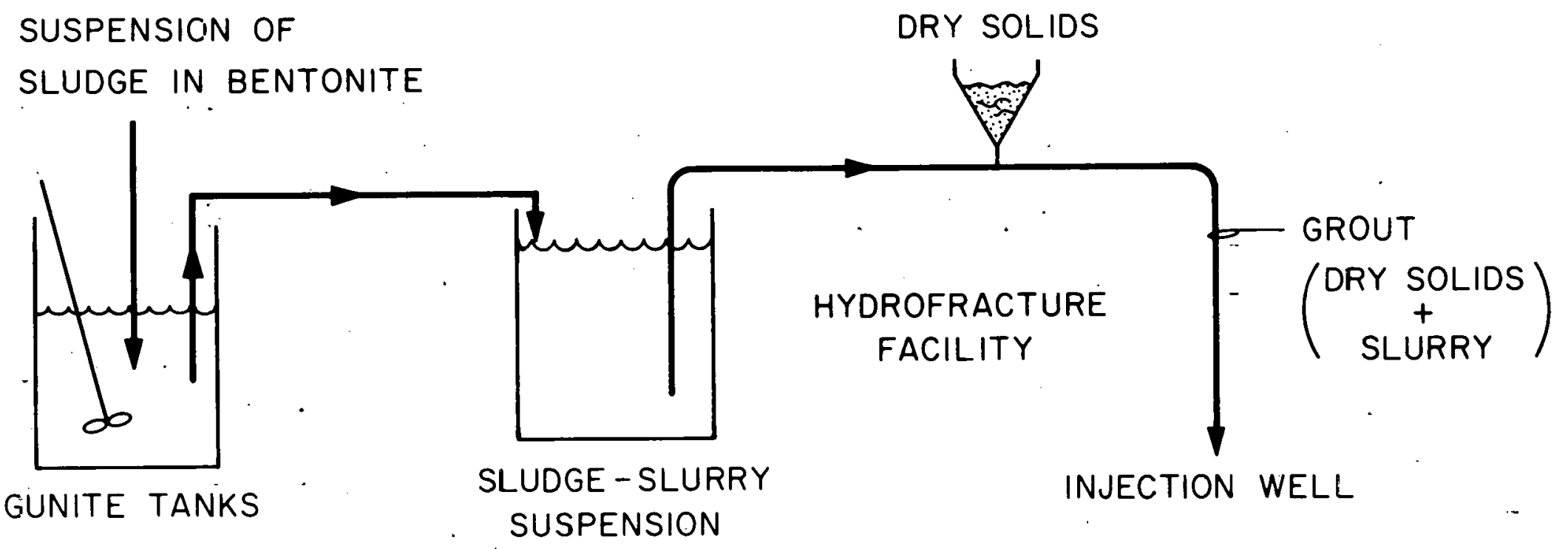

Fig. 1. Flow diagram of sludge-slurry grout hydrofacture process. 
constant temperature and pressure. A Newtonian fluid will begin to flow immediately when pressure is applied.

The term non-Newtonian describes all fluids whose behavior is different from that of a Newtonian fluid. ${ }^{3}$ These are rheologically complex, frequently particle-bearing fluids. Non-Newtonian fluids do not exhibit a direct proportionality between pressure loss and flow rate at constant temperature and pressure. Some non-Newtonian fluids do not start to flow immediately after a force is applied, but will go through stages of flow (i.e., plug, laminar, and turbulent).4

A complex type of non-Newtonian tluid is pseuduplastic, which includes the majority of industrial fluids. The apparent viscosities of these fluids decrease as shear rates increase. An empirical relationship known as the power law (Sect. 2.1) is most of ten used to characterize fluids of this type. Other non-Newtonian fluids are thixotroplc. These fluids possess structure, and the breakdown of thls slructurc io a funstion of time and shear rate. As the structure breaks down, the shear stress decreases with constant shear rate. This structure can rebuild itself if it is not prevented from doing so by externally applied forces. Other classifications exist, and their descriptions may be found in the literature. 3,4

The literature indicates that the flow behavior of cement elurries is non-Newtonian and is described best by the power law method of analysis. ${ }^{4}$ All flow characteristics described in this report are inlerpreted using this model.

Dry-solids slurry-mixing experillents wcre conducled in the laboratory using only those physical properties that can be rcadily determined in the field on the actual sludge-grout mix. These include, for example, the slurry viscosity and density. The unclerlying assumption that formed the basis of the measurements was that a sludge-slurry suspension of a given viscosity may be mixed with a dry-solids cement blend until the power required to mix the grout at a predetermined speed was equal to that of a reference mix. The resulting grout should then exhibit rheological properties similar to those of the reference grout. A series of grouts was made with sludge-slurries of increasing viscosities. The data 
derived from the mixes were used to establish a series of rheograms. The rheograms relate the power required to mix the slurry-grout to that required to mix a reference grout. These curves are then used to calculate the quantity of dry solids to be added to a sludge-slurry of known viscosity.

\subsection{Power Law Mode1}

The power law model is based on the assumption that a fluid exhibits a proportionality between the logarithm of the pressure loss and the logarithm of the flow rate in the region of laminar flow. ${ }^{4} \mathrm{~A} 10 \mathrm{l}-1 \mathrm{log}$ plot of shear stress vs shear rate is constructed to obtain the two parameters required to define the power law model. The intercept of this line at unit shear rate is called the fluid consistency index. This index is denoted by $K^{\prime}$. The slope of the line, $n^{\prime}$, is referred to as the flow behavior index and is a measure of the non-Newtonian behavior of the fluid; for pseudoplastics, $0<n^{\prime}<1$. Newtonian fluids have a flow behavior index of unity, and, in addition to $K^{\prime}$ and $n^{\prime}$, flow calculations are usually based on a Reynolds number correlation. The following equation is used to calculate the velocity (flow rate) at a specific Reynolds number. ${ }^{4}$

$$
V=\left[\frac{N_{r e^{K^{\prime}}\left(96 / d_{i}\right)^{n^{\prime}}}}{1.860}\right]^{\frac{1}{2-n^{\prime}}},
$$

where

$$
\begin{aligned}
V= & \text { velocity, } \mathrm{ft} / \mathrm{s} ; * \\
N_{r e}= & \text { Reynolds number, dimensionless; } \\
K^{\prime}= & \text { consistency index, Ibf } \cdot \mathrm{s}^{\prime} / \mathrm{ft}^{2} ; \\
d_{i}= & \text { ratio of four times the area of the flow to the wetted } \\
& \text { perimeter, in.; } \\
D= & \text { fluid density, lb/gal; } \\
n^{\prime}= & \text { flow behavior index; dimensionless. }
\end{aligned}
$$

*To convert from $\mathrm{ft} / \mathrm{s}$ to $\mathrm{m} / \mathrm{s}$, multi-yly by 0.3048 . 
A Reynolds number of 2100 is the accepted value for the start of turbulence in cement slurry-flow calculations. This $N_{r e}$ is used in all calculations presented in this report.

\section{EXPERIMENT AND RESULTS}

\subsection{Determination of Flow Property Reference Points}

A series of duplicate grout mixes was made to determine the average flow properties (Tables 1 and 2 ) for grouts that have routinely been pumped during the hydrofracture disposal of waste solutions. These mixeo were assumed to have acceptable phase separation and viscosity. The average critical velocity for these mixtures was used as a reference for all flow characteristic measurement of grouts made with more viscous sludge-slurries. The sludge-slurries require the addition of less dry solids to yield an equal critical velocity. The experimental objectivc was to establish a rheogram relating the apparent viscosity of a slurry of simulated radioactive sludge to the dry mix-to-slurry ratio required to maintain a grout that can be pumped.

Table 1. Flow properties ${ }^{a}$ of $719.0-g / \ell(6.0-1 b / g a 1)$ reference grout

\begin{tabular}{|c|c|c|c|c|c|c|}
\hline \multicolumn{2}{|c|}{ Flow parameters } & \multirow{2}{*}{$\begin{array}{l}\text { Phase } \\
\text { separat lon } \\
(\operatorname{vol} \%)\end{array}$} & \multicolumn{2}{|c|}{ Density } & \multicolumn{2}{|c|}{ Viscosity } \\
\hline $\begin{array}{c}\text { Fluid consistency } \\
\text { index }\left(K^{\prime}\right)\end{array}$ & $\begin{array}{l}\text { Flow behavior } \\
\text { index }\left(n^{\prime}\right)\end{array}$ & & $\mathrm{g} / \mathrm{cm}^{3}$ & $1 \mathrm{~b} / \mathrm{gal}$ & $\mathrm{Pa} \cdot \mathrm{s}$ & sP \\
\hline $3.55 \times 10^{-3}$ & 0.61 & 4.92 & 1.40 & 11.65 & 0.016 & 16 \\
\hline $7.75 \times 10^{-3}$ & 0.50 & 4.10 & 1.40 & 11.65 & 0.018 & 18 \\
\hline $3.97 \times 10^{-3}$ & 0.58 & 4.90 & 1.40 & 11.65 & 0.014 & 14 \\
\hline $6.43 \times 10^{-3}$ & 0.53 & 4.17 & 1.40 & 11.65 & 0.018 & 18 \\
\hline $1.95 \times 10^{-3}$ & 0.68 & 4.07 & 1.40 & 11.65 & 0.013 & 13 \\
\hline $2.92 \times 10^{-3}$ & 0.61 & 4.96 & 1.40 & 11.65 & 0.013 & 13 \\
\hline $\bar{X} 4.43 \times 10^{-3 b}$ & 0.59 & 4.52 & 1.40 & 11.65 & 0.015 & 15 \\
\hline$S 0.022$ & 0.06 & 0.45 & 0.00 & 0.0 & 0.002 & 2. \\
\hline
\end{tabular}

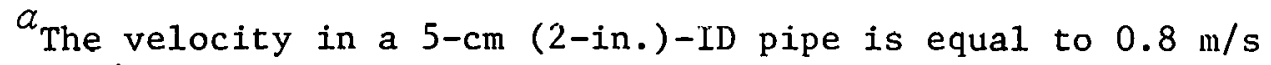
(27.2 gal/min).

$b_{\bar{X}}=$ arithmetic average; $S=$ standard deviation. 
Table 2. Flow properties ${ }^{a}$ of $958.0-\mathrm{g} / \ell(8.0-1 \mathrm{~b} / \mathrm{gal})$ reference grout

\begin{tabular}{|c|c|c|c|c|c|c|}
\hline \multicolumn{2}{|c|}{ Flow parameters } & \multirow{3}{*}{$\begin{array}{c}\text { Phase } \\
\text { Separation } \\
(\operatorname{vol} \%)\end{array}$} & \multirow{2}{*}{\multicolumn{2}{|c|}{ Density }} & \multirow{2}{*}{\multicolumn{2}{|c|}{ Viscosity }} \\
\hline \multirow{2}{*}{$\begin{array}{c}\text { Fluid consistency } \\
\text { index }\left(K^{\prime}\right)\end{array}$} & \multirow{2}{*}{$\begin{array}{l}\text { Flow behavior } \\
\text { index }\left(n^{\prime}\right)\end{array}$} & & & & & \\
\hline & & & $\mathrm{g} / \mathrm{cm}^{3}$ & $1 \mathrm{~b} / \mathrm{gal}$ & $\mathrm{Pa} \cdot \mathrm{s}$ & $\mathrm{cP}$ \\
\hline $3.16 \times 10^{-2}$ & 0.43 & 0.83 & 1.46 & 12.2 & 0.045 & 45 \\
\hline $4.59 \times 10^{-2}$ & 0.38 & 0.56 & 1.47 & 12.3 & 0.050 & 50 \\
\hline $4.81 \times 10^{-2}$ & 0.38 & 0.72 & 1.46 & 12.2 & 0.051 & 51 \\
\hline $6.10 \times 10^{-2}$ & 0.32 & 0.30 & 1.49 & 12.4 & 0.042 & 42 \\
\hline $5.70 \times 10^{-2}$ & 0.32 & 0.0 & 1.49 & 12.4 & 0.040 & 40 \\
\hline $9.0 \times 10^{-2}$ & 0.26 & 0.0 & 1.49 & 12.4 & 0.044 & 44 \\
\hline $\bar{X} 5.56 \times 10^{-2 b}$ & 0.35 & 0.40 & 1.48 & 12.3 & 0.045 & 45.3 \\
\hline$S 0.02^{b}$ & 0.06 & 0.36 & 0.02 & 0.10 & 0.004 & 4.4 \\
\hline
\end{tabular}
min).

$a_{\text {The velocity in a } 5-\mathrm{cm}(2-i n .)-I D}$ pipe is equal to $1.90 \mathrm{~m} / \mathrm{s}(60.5 \mathrm{gal} /$ $b_{\bar{X}}=$ arithmetic average; $S=$ standard deviation.

The apparent viscosity is the viscosity a fluid appears to have at a stated shear rate. It is a function of the plastic viscosity, which is the resistance to flow caused by friction between suspended particles and by the viscosity of the liquid phase, and the yield point, which is a measure of the forces which cause a gel structure to develop when the slurry is at rest.

The grout made at the hydrofracture facility to dispose of the waste supernate used a solids/liquid ratio predetermined in a series of laboratory tests. This procedure was modeled in the laboratory by preparing simulated waste solutions based on chemical analyses of actual waste solutions in the ORNL waste storage tanks. ${ }^{2}$ Mixing was performed by adding dry solids slowly to the waste solution over a 15-s period while stirring followed by continued stirring for an additional $15 \mathrm{~s}$ at the same mix speed. A speed of $2000 \mathrm{rpm}$ was used to simulate grout mixed in the plant mixer tub.

The grout resulting from mixing dry solids with a sludge-slurry suspension should have properties fairly similar to those used in the disposal of ILW waste solutions. Previous work has shown that even though other 
characteristics of grouts may vary greatly, they could exhibit similar pumping properties and phase separation. 4-7

\subsection{Equipment and Mixing}

A laboratory mixer with an electronic speed control was used for all mixes. A sensitive ampmeter was used to detect changes in the current required to maintain a constant mixing speed. The power required to maintain a constant speed should be proportional to the viscosity of the mix. The current required as dry $\mathrm{mix}$ was added to a simulated waste solution was compared with the current required for mixing more viscous sludgeslurries. It is assumed that although the individual flow parameters of the grouts may vary, grouts that require equal current for mixing would display similar flow (pumping) characteristics. Multiple measurements were made for the reference grouts. The compositiono of the dry solids are shown in Table 3. The standard mixing procedure at $2000 \mathrm{rpm}$ was followed.

Table 3. Composition of dry solids used in reference grouts

\begin{tabular}{lr}
\hline Material & wt \% \\
\hline Type I Portland cement & 38.5 \\
Kingston fly ash & 38.5 \\
Attapulgite drilling clay & 15.3 \\
Indian Red pottery clay & 7.7 \\
\hline
\end{tabular}

Reference mixes were made in the ratio of $719.0 \mathrm{~g} / \ell(6.0 \mathrm{lb} / \mathrm{gd} 1)$ and $958.0 \mathrm{~g} / \ell(8.0 \mathrm{lb} / \mathrm{gal})$. Reference mix data are listed in lablès 2 and 3. A Fann viscometer* was used to measure the shear stress at various shear rates. The grout density was determined with a Baroid mud balance.

*Manufactured by Fann Instrument Company, Houston, Tex. 


\subsection{Slurries}

The properties of the sludge-slurry suspension must be controlled within limits that will permit blending with sufficient dry solids to produce an acceptable grout. The properties of the suspension are a complex function of not only the components of the solids but also the particle size and number and forces between the particles, as well as the viscosity of the base liquid. A measurement that takes into account all of these factors at a single stage of flow 1s extremely complicated and requires a variable-speed direct-indicating viscometer. Such a measurement would be difficult and impractical to make at the waste transfer site. Even though such measurements are necessary for laboratory experiments, flow property changes in this report are related to parameters such as the density and the viscosity that can be either measured or estimated at the waste disposal site.

Various metal and/or metal oxides suspended with 2.0 wt \% commercialgrade bentonite clay* in a $0.1 \mathrm{M} \mathrm{NaNO}_{3}$ solution were used as simulated sludge-slurries. (Table 4 ).

Table 4. Surface area, particle size, and density of suspended solids

\begin{tabular}{lccc}
\hline Material & $\begin{array}{c}\text { Surface area } \\
\left(\mathrm{m}^{2} / \mathrm{g}\right)\end{array}$ & $\begin{array}{c}\text { Particle size } \\
(\mu \mathrm{m})\end{array}$ & $\begin{array}{c}\text { Density } \\
\left(\mathrm{g} / \mathrm{cm}^{3}\right)\end{array}$ \\
\hline Bentonite & 35.96 & 7.22 & 2.32 \\
Iron metal & 0.20 & 24.99 & 7.59 \\
$\mathrm{Fe}_{2} \mathrm{O}_{3}$ & 9.21 & 3.47 & 5.15 \\
$\mathrm{Fe}_{3} \mathrm{O}_{4}$ & 1.81 & 29.41 & 4.78 \\
$\mathrm{Al}_{2} \mathrm{O}_{3}$ & 0.75 & 54.00 & 3.96 \\
Ottawa sand & 0.029 & 370.00 & 2.64 \\
\hline
\end{tabular}

Maximuin size of $50 \%$ of the particles.

*The bentonite used was commercial-grade Wyoming bentonite that is listed in Table 5 as Thixogel \#2. 
An area of interest in the compatibility testing of sludge-slurry grout is the effect of surface area and particle size on the viscosity and settling rate. Many investigations into the significance of particle size are reported in the literature. ${ }^{8}$ Although no detailed study was made here, the trend was for the smaller particles to produce more viscous suspensions. This characteristic was used to its fullest advantage when slurries having equal solids contents but different viscosities were ne.e.ded. Sand was too coarse to be suspended in a $2.0 \mathrm{wt} \%$ bentonite slurry. Other materials (Table 5) were tested as possible suspenders, but none were found to perform as well as bentonite.

Table 5. Materials evaluated as possible suspending agents

\begin{tabular}{|c|c|c|}
\hline Trade name & Supplier & Type \\
\hline Aquage1 & Baroid Petroleum Services & $\begin{array}{l}\text { Selected fine-ground } \\
\text { bentonite }\end{array}$ \\
\hline Zeage1 & Baroid Petroleum Services & Attapulgite \\
\hline $\mathrm{XC}$ Polymer & Baroid Petroleum Services & Organic \\
\hline Cellex & Baroid Petroleum Services & Sodium carboxmethylcellulose \\
\hline Thixogel \# 1 & Georgia Kaolin & Wyoming bentonite \\
\hline Ihixoge1 \# 2 & Geurgiä Kaolin & Wyoming bentonite \\
\hline $\begin{array}{l}\text { Mineral Colloid } \\
\mathrm{BP}\end{array}$ & Georgia Kaolin & Pure montmorillonite \\
\hline Gelwhite L & Georgia Kaolin & Montmorillonite (white) \\
\hline Quikge1 & Baroid Petroleum Šervices & High-ÿiëld benconlte \\
\hline Lo Loss & Baroid Petroleum Services & Oganic colloid \\
\hline
\end{tabular}

\subsection{Sludge-Slurry Grouts}

Slurries of different viscosities were made using 15.0 wt $\%$ metal oxides and/or metal particles suspended with 2.0 wt \% bentonite clay in a $0.1 \mathrm{M} \mathrm{NaNO}_{3}$ solution. To these was add $\epsilon \mathrm{d}$ a dry-solids blend composed of 46.0 wt \% Type I Portland cement, 46.0 wt \% Kingston fly ash, and 8.0 wt \% Indian Red Pottery clay until the mixing current equaled that of a reference grout. The resulting data are listed in Tables 6 and 7 . 
Table 6. Flow properties of grouts extrapolated from $719.0-\mathrm{g} / \mathrm{l}(6.0-1 \mathrm{~b} / \mathrm{gal}$ dry solids in a simulated waste solution-reference velocity of $0.8 \mathrm{~m} / \mathrm{s}(2.8 \mathrm{ft} / \mathrm{s})$

\begin{tabular}{|c|c|c|c|c|c|c|c|c|c|c|c|c|}
\hline \multicolumn{2}{|c|}{$\begin{array}{c}\text { Slurry }^{a} \\
\text { viscosity }\end{array}$} & \multicolumn{2}{|c|}{$\begin{array}{c}\text { Grout } \\
\text { viscosity }\end{array}$} & \multicolumn{2}{|c|}{$\begin{array}{l}\text { Dry solids } \\
\text { added }\end{array}$} & \multicolumn{2}{|c|}{$\begin{array}{l}\text { Grout } \\
\text { density }\end{array}$} & \multicolumn{2}{|c|}{$\begin{array}{l}\text { Critical } \\
\text { velocity }\end{array}$} & \multirow{2}{*}{$\begin{array}{c}\text { Phase } \\
\text { sep. } \\
\text { vol. } \\
(\%)\end{array}$} & \multicolumn{2}{|c|}{ Flow parameters } \\
\hline$P \approx \bullet s$ & $c P$ & $\mathrm{~Pa} \cdot \mathrm{s}$ & $c P$ & $\mathrm{~g} / \mathrm{cm}^{3}$ & $1 \mathrm{~b} / \mathrm{ga} 1$ & $\mathrm{~g} / \mathrm{cm}^{3}$ & lb/gal & $\mathrm{m} / \mathrm{s}$ & $\mathrm{ft} / \mathrm{s}$ & & index $\left(K^{\prime}\right)$ & $\begin{array}{l}\text { Flow behavior } \\
\text { index }\left(n^{\prime}\right)\end{array}$ \\
\hline 0.0035 & 3.5 & 0.0270 & 27.0 & 0.6 .6 & 5.5 & 1.43 & 11.96 & $1: 33$ & 4.40 & 3.64 & $4.81 \times 10^{-2}$ & 0.27 \\
\hline 0.0045 & 4.5 & 0.0273 & 27.0 & $0 . € 6$ & 5.5 & 1.40 & 11.65 & 1.43 & 4.72 & 2.01 & $6.60 \times 10^{-2}$ & 0.23 \\
\hline 0.0075 & 7.5 & 0.0375 & 37.5 & 0.60 & 5.0 & 1.39 & 11.60 & 1.74 & 5.71 & 1.82 & $1.22 \times 10^{-1}$ & 0.18 \\
\hline 0.0085 & 8.5 & 0.0335 & 33.5 & 0.54 & 4.5 & 1.37 & 11.40 & 1.57 & 5.16 & 1.42 & $1.19 \times 10^{-1}$ & 0.16 \\
\hline $0.0 \supset 90$ & 9.0 & 0.0330 & 33.0 & 0.54 & 4.5 & 1.36 & 11.35 & 1.60 & 5.26 & 2.10 & $1.03 \times 10^{-1}$ & 0.18 \\
\hline 0.0120 & 12.0 & 0.0260 & 26.0 & 0.30 & 2.5 & 1.28 & 10.65 & 1.45 & 4.75 & 4.96 & $5.48 \times 10^{-2}$ & 0.25 \\
\hline \multirow[t]{3}{*}{0.0130} & 13.0 & 0.0270 & 27.0 & 0.24 & 2.0 & 1.27 & 10.60 & 1.50 & 4.91 & 4.10 & $5.48 \times 10^{-2}$ & 0.25 \\
\hline & & & & & & & $\bar{X}=11.31^{c}$ & 1.52 & 4.98 & & $8.11 \times 10^{-2}$ & 0.22 \\
\hline & & & & & & & $S=0.51^{c}$ & 0.13 & 0.43 & & 0.03 & 0.04 \\
\hline
\end{tabular}

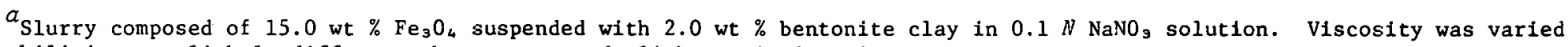
by stabilizing at slightly different sheaz rates and slight variations in $\mathrm{pH}$.

${ }^{b}$ Critical velocity for flow in a 5 -cn (2-in.)-ID tube. Flow rate would be $23.2 \ell / \mathrm{s}$ ( 50 gal/min;. A hydrofracture injection is normally made at a flow rate of 16 to $-7 \mathrm{l} / \mathrm{s}$ ( 250 to $275 \mathrm{gal} / \mathrm{min}$;.

${ }^{c} \bar{X}=$ arithmetic average; $S=$ standard deviation. 
Table 7. Flow proferzies of grouts extrapolated from $959.0-\mathrm{g} / \ell(8.0-1 \mathrm{~b} / \mathrm{gal}) \mathrm{dry}$ solids in a simulated waste solution reference velocity of $1.9 \mathrm{~m} / \mathrm{s}(6.2 \mathrm{ft} / \mathrm{s})$

\begin{tabular}{|c|c|c|c|c|c|c|c|c|c|c|c|c|}
\hline \multicolumn{2}{|c|}{$\begin{array}{c}\text { Slurry }^{a} \\
\text { viscosity }\end{array}$} & \multicolumn{2}{|c|}{$\begin{array}{c}\text { Grout } \\
\text { viscosity }\end{array}$} & \multicolumn{2}{|c|}{$\begin{array}{l}\text { Dry solids } \\
\text { addec }\end{array}$} & \multicolumn{2}{|c|}{$\begin{array}{l}\text { Grout } \\
\text { density }\end{array}$} & \multicolumn{2}{|c|}{$\begin{array}{l}\text { Critical } b \\
\text { velocity }\end{array}$} & \multirow{2}{*}{$\begin{array}{c}\text { Phase } \\
\text { sep. } \\
\text { vol. } \\
(\%)\end{array}$} & \multicolumn{2}{|c|}{ Flow parameters } \\
\hline $\mathrm{Pa} \cdot \mathrm{s}$ & cP & $\mathrm{Pa} \cdot \mathrm{s}$ & cP & $3 / \mathrm{cm}^{3}$ & $\Xi \mathrm{b}_{\mathrm{g}} \mathrm{ga}-$ & $\mathrm{g} / \mathrm{cm}^{3}$ & 1b/gal & $\mathrm{m} / \mathrm{s}$ & $\mathrm{ft} / \mathrm{s}$ & & $\begin{array}{l}\text { Filld consistency } \\
\text { index }\left(K^{\prime}\right)\end{array}$ & $\begin{array}{l}\text { Flow behavior } \\
\text { index }\left(n^{\prime}\right)\end{array}$ \\
\hline 0.0630 & 3.0 & 0.0505 & 50.5 & 1. 32 & 11.0 & 1.62 & 13.5 & 1.89 & 6.21 & 0.84 & $1.28 \times 10^{-1}$ & 0.23 \\
\hline 0.0060 & 6.0 & 0.0660 & 66.0 & 1.17 & 9.8 & 1.60 & 13.35 & 2.16 & 7.10 & 1.10 & $1.40 \times 10^{-1}$ & 0.25 \\
\hline 0.0095 & 9.5 & 0.0365 & 36.5 & 3.96 & 8.0 & 1.57 & 12.60 & 1.76 & 5.79 & B. 10 & $9.07 \times 10^{-2}$ & 0.24 \\
\hline 0.0120 & 12.0 & 0.0465 & 46.5 & 0.9 & 7.5 & 1.51 & 12.65 & 1.85 & 6.09 & 0.48 & $1.25 \times 10^{-1}$ & 0.21 \\
\hline 0.0160 & 16.0 & 0.0480 & 48.0 & 0.63 & 5.25 & 1.42 & 11.85 & 1.97 & 6.47 & 3.30 & $1.56 \times 10^{-1}$ & 0.18 \\
\hline $0.0 i 7$ & 17.0 & 0.0550 & 55.0 & 0.60 & 5.0 & 1.41 & 11.80 & 2.17 & 7.12 & 2.0 & $1.92 \times 10^{-1}$ & 0.17 \\
\hline \multirow[t]{3}{*}{0.019} & 19.0 & $0.0580^{\circ}$ & 58.0 & 0.48 & 4.0 & 1.37 & 11.40 & 2.07 & 6.79 & 2.70 & $1.85 \times 10^{-1}$ & 0.16 \\
\hline & & & & & & $\bar{X}$ & 12.45 & 1.98 & 6.51 & & $1.45 \times 10^{-1}$ & 0.21 \\
\hline & & & & & & $S$ & 0.80 & 0.16 & 0.51 & & 0.04 & 0.04 \\
\hline
\end{tabular}

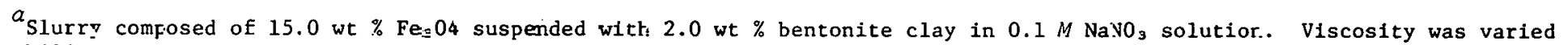
by stabilizing at slightly different shear rates and sight variations in $\mathrm{pH}$.

\footnotetext{
${ }^{b}$ Critical velocity for flow in 5-ch (2-in.) -II tube. Flow rate would be 44.0 lis (64 gal/min).
} 
Data from Tables 6 and 7 are plotted in Fig. 2. The lower curve pertains to the flow parameters of $719-\mathrm{g} / \ell$ supernate grouts (Table 1 ). The upper curve represents grouts referenced to $958 \mathrm{~g} / \ell$ (Table 2). The sludge-slurry grouts were found to have a much higher critical velocity for turbulent flow than the $719-\mathrm{g} / \ell$ reference grout. However, the velocities were essentially the same as the higher solids/liquid reference grout. Thus, for field application, one would use the upper line representing the higher reference grout.

\subsection{Effect of $\mathrm{pH}$ on Sludge-Slurry Viscosity}

In the neutralization of ILW, a $\mathrm{pH} \geq 9.5$ is necessary to ensure the complete precipitation of ${ }^{90} \mathrm{Sr}(\mathrm{OH})_{2}$. Slight variations in the $\mathrm{pH}$ in this region ( 9 to 12) were found to have a major effect on the viscosity of a sludge-slurry suspended with bentonite. The viscosities were determined for a 15.0 wt $\% \mathrm{Fe}_{3} \mathrm{O}_{4}$ slurry suspended with 2.0 wt \% bentonite in a $0.1 \mathrm{M} \mathrm{NaNO}_{3}$ solution as a function of $\mathrm{pH}$. At each point, the slurry was sheared by stirring until maximum viscosity was reached. The $\mathrm{pH}$ was then increased, and stirring was repeated (Fig. 3). Extreme shearing conditions were used in this experiment and are 2200 times greater than that expected in the actual injections. Maximum viscosity was reached at a $\mathrm{pH}$ of 11.2 and then decreased as the $\mathrm{pH}$ increased.

\subsection{The Use of Chemical Additives to Control Flow Properties of Sludge-Slurries and Cementitious Grouts}

There are several types of chemical compounds that may be used to change the flow properties of non-Newtonian liquid. For example, tannins, lignites, polyphosphates, and lignosulfonates are the compounds which the oil industry has found to be the most effective "thinners." Each of these material has 1 ts optimum effectiveness under certain conditions and within a definite $\mathrm{pH}$ range. Polyphosphates are rarely used if the pll exceeds 10. Tannins are effective if the $\mathrm{pH}$ is $\geq 8$, and lignites work best between $\mathrm{a} \mathrm{pH}$ of 8.5 and 9.5 . The action of these compounds when added to 
VISCOSITY 0: 15 wt \% SLUDGE-SLURRY (cP)

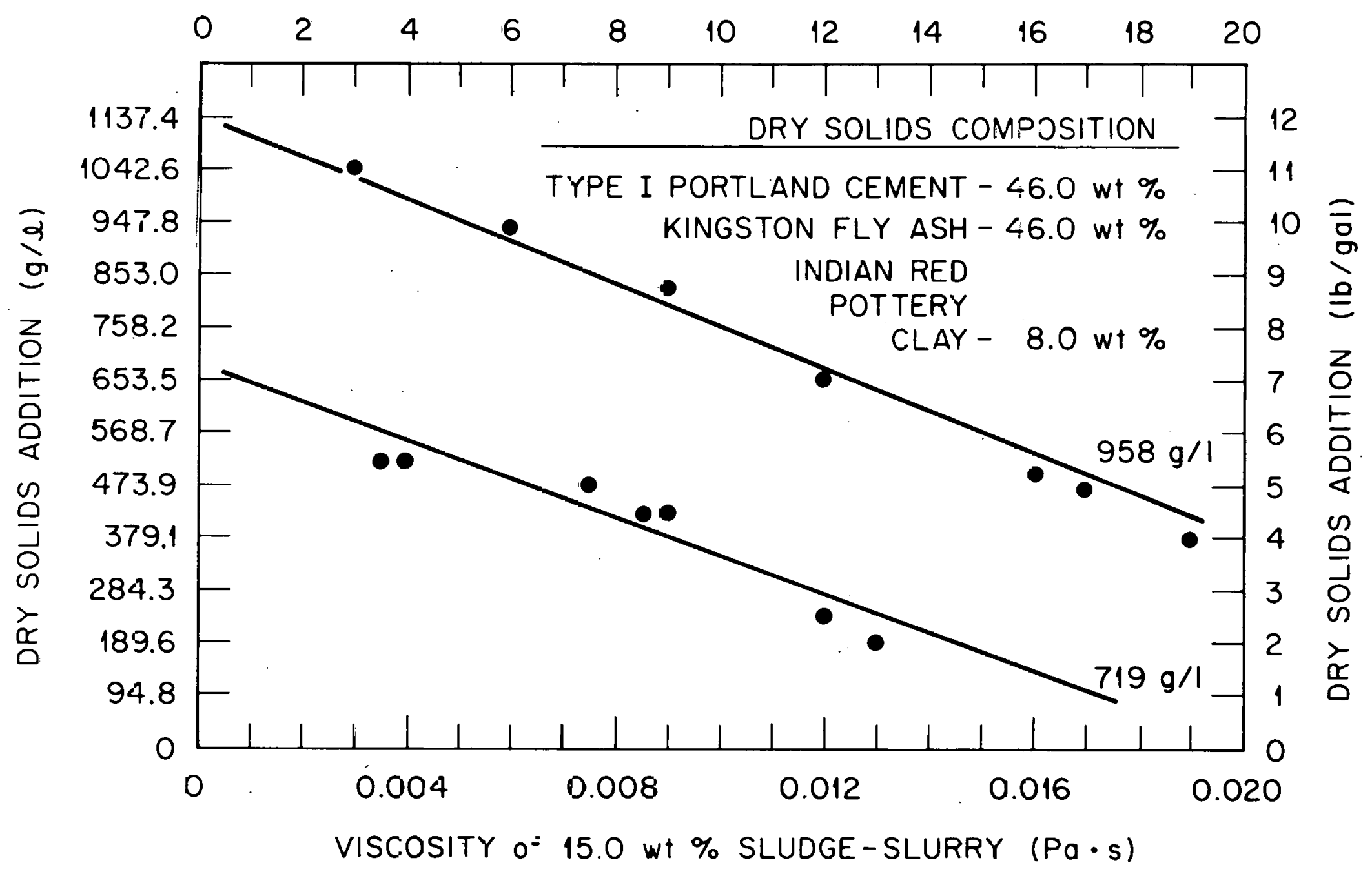

Fig. 2. Rheogram tinat relates the flow properties of a sludge-slurry grout to one made with waste solution. 
ORNL DWG 80-972 R

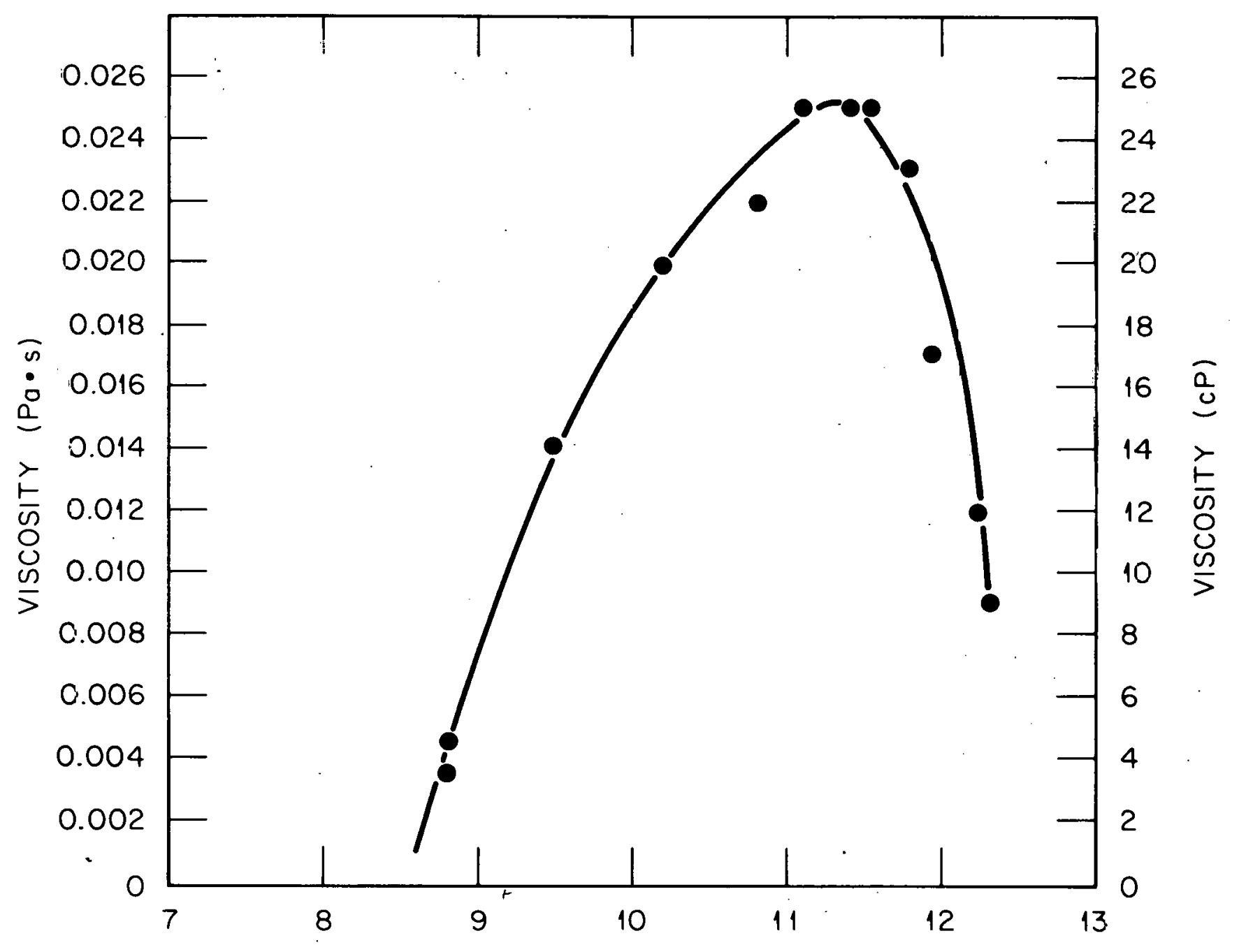

$\mathrm{pH}$ of 15.0 wi \% SLUDGE SUSPENDED WITH $2.0 \%$ BENTONITE

Fig. 3. Viscosity of a sludge-slurry as a function of $\mathrm{pH}$. 
a fluid to lower the velocity required for turbulent flow is thought to be that they complete broken valence bonds, thus reducing interparticle forces. 9

Additives more closely related to cementing are the friction reducers and plasticizers. Friction reducers are essentially dispersing agents which reduce the apparent viscosity of the slurry with no change in flow rate. A lower apparent viscosity gives a higher Reynolds number and therefore a lower Fanning friction factor and a lower critical velocity. ${ }^{4}$ Plasticizers increase the fluidity of a cement slurry for a given waterto-solids ratio. Friction reducers and plasticizers may be conveniently added to a dry solids blend. Data related to those chemicals are well covered in the literature. 4,7,8,10 Caution must be exercised in using chemicals to control flow propertles of radioactive sludge-slurries and. grouts because of the uncertainity of slurry composition. Chemical additives evaluated in this study along with comments are listed in Tables 8 to 10 .

Table 8. Chemical additivies evaluated to alter flow properties of sludge slurrice and sementitious grouts

\begin{tabular}{|c|c|c|c|}
\hline Trade name & Supplier & Type & Comments \\
\hline Barafos & Baroid & Sodium pyrophosphate & Effective \\
\hline Q-Broxin & Baroid & $\begin{array}{l}\text { Heavy-metal ligno- } \\
\text { sulfunale. }\end{array}$ & $\begin{array}{l}\text { Effective over wide } \mathrm{pH} \\
\text { range and in the presenc } \\
\text { of various electrolites }\end{array}$ \\
\hline Carbonox & Baroid & Lignite & $\begin{array}{l}\text { Calcium acto ac a con- } \\
\text { taminant In llie presencc } \\
\text { of lignites }\end{array}$ \\
\hline $\mathrm{CC}-16$ & Baroid & Treated lignite & $\begin{array}{l}\text { Increases pH; calcium } \\
\text { decreases effectiveness }\end{array}$ \\
\hline
\end{tabular}

Entanding the mixing time of $15.0 \mathrm{wt} \%$ sludge slurries changes the flow behavior index (i.e., the slurry becomes less Newtonian). The velocity required for turbulent flow is reduced by the addition of $\mathrm{FX}=32 \mathrm{C}$ and is not adversely affected by increasing mix time. (Table 11).

The effects of several of the potential additivcs on the flow properties of a grout are listed in Table 12. The FX-32C drastically 
Table 9. Friction reducers

\begin{tabular}{|c|c|c|c|}
\hline Trade name & Supplier & Type & Comments \\
\hline CFR-1 & Halliburton & $\begin{array}{l}\text { Delta gluconol- } \\
\text { acetone }\end{array}$ & $\begin{array}{l}\text { Added to dry solids; re- } \\
\text { duces critical velocity } \\
\text { of cement slurries neces- } \\
\text { sary for turbulent flow; } \\
\text { uses up to } 0.3 \text { wt } \% \text {; most } \\
\text { effective in.slurries not } \\
\text { containing bentonite }\end{array}$ \\
\hline CFR-2 & Halliburton & $\begin{array}{l}\text { Proprietary } \\
\text { compound }\end{array}$ & $\begin{array}{l}\text { Reduces velocity required } \\
\text { for turbulent. flow; up to } \\
2.0 \% \text { may be used; effec- } \\
\text { t1ve in high gel-cement }\end{array}$ \\
\hline $\mathrm{HR}-7$ & Halliburton & $\begin{array}{l}\text { Proprietary } \\
\text { compound }\end{array}$ & $\begin{array}{l}\text { Effective in high gel- } \\
\text { cement. }\end{array}$ \\
\hline Halad-9 & Halliburton & $\begin{array}{l}\text { Proprietary } \\
\text { compound }\end{array}$ & $\begin{array}{l}\text { Effective in high gel- } \\
\text { cement }\end{array}$ \\
\hline
\end{tabular}

Table 10. Plasticizers

\begin{tabular}{|c|c|c|c|}
\hline Trade name & Supplier & Type & Comments \\
\hline $\begin{array}{l}F X-32 C \\
F X-32 D\end{array}$ & Fox Industries & $\begin{array}{l}\text { Sulfonated naphthalene } \\
\text { formaldehyde conden- } \\
\text { sate }\end{array}$ & $\begin{array}{l}\text { Produces very fluid } \\
\text { grouts }\end{array}$ \\
\hline Plastiment & Sika & $\begin{array}{l}\text { Metallic salt of hydro- } \\
\text { xylated carboxylic } \\
\text { acid }\end{array}$ & $\begin{array}{l}\text { Water-reducing re- } \\
\text { tarder }\end{array}$ \\
\hline Melment & $\begin{array}{l}\text { American } \\
\text { Admixtures }\end{array}$ & $\begin{array}{l}\text { Sulfonated melamine } \\
\text { formaldehyde conden- } \\
\text { sate }\end{array}$ & $\begin{array}{l}\text { Liquid or dry solid } \\
\text { effective water } \\
\text { reducer }\end{array}$ \\
\hline$D-65$ & Dowe11 & $\begin{array}{l}\text { Sodium salt of organic } \\
\text { phosphate }\end{array}$ & $\begin{array}{l}\text { Effective dry-solid } \\
\text { fluidizer }\end{array}$ \\
\hline
\end{tabular}


Table 11. Effect of adding $0.2 \mathrm{wt} \% \mathrm{FX}-32^{\alpha}$ on the flow properties of a 15 wt \% sludge-slurry

\begin{tabular}{|c|c|c|c|c|c|c|}
\hline \multirow{3}{*}{$\begin{array}{c}\text { Flow } \\
\text { parameter }\end{array}$} & \multicolumn{6}{|c|}{ Mixing time (s) } \\
\hline & \multicolumn{2}{|c|}{60} & \multicolumn{2}{|c|}{600} & \multicolumn{2}{|c|}{3600} \\
\hline & 0 wt $\%$ & 0.2 wt $\%$ & 0 wt $\%$ & 0.2 wt $\%$ & 0 wt $\%$ & 0.2 wt $\%$ \\
\hline$K^{\prime}$ & $1.6 \times 10^{-2}$ & $2.7 \times 10^{-3}$ & $3.5 \times 10^{-2}$ & $3.3 \times 10^{-3}$ & $4.1 \times 10^{-2}$ & $6.4 \times 10^{-3}$ \\
\hline$n^{\prime}$ & 0.32 & 0.48 & 0.24 & 0.46 & 0.19 & 0.34 \\
\hline$V, \mathrm{~m} / \mathrm{s}$ & 0.94 & 0.49 & 1.16 & 0.52 & 1.10 & 0.57 \\
\hline$f / s$ & 3.08 & 1.51 & 3.81 & 1.71 & 3.61 & 1.87 \\
\hline $\begin{array}{c}\text { Density, } \\
\mathrm{g} / \mathrm{cm}\end{array}$ & 1.138 & 1.138 & 1.138 & 1.138 & 1.138 & 1.138 \\
\hline 1b/gal & 9.47 & 9.47 & 9.47 & 9.47 & 9.47 & 9.47 \\
\hline
\end{tabular}

$C_{15.0}$ wt. \% $\mathrm{Fe}_{2} \mathrm{O}_{3}$ suspended with $2.0 \mathrm{wt} \%$ bentonite clay in 0.1 M solution (pH 9.5). Mixed at $2000 \mathrm{rpm}$. 
Table 12. Effect of additives on sludge-slurry grouts

\begin{tabular}{|c|c|c|c|c|}
\hline \multirow{2}{*}{ Flow parameter } & \multicolumn{4}{|c|}{ Additive to $959.0-\mathrm{g} / \ell(8.0-1 \mathrm{~b} / \mathrm{gal})$ dry solids ${ }^{\ddot{u}}$} \\
\hline & a wt \% & 1.0 wt $\% \mathrm{FX}-32 \mathrm{C}$ & 1.0 wt $\%$ Q Broxin & 1.0 wt $\% \mathrm{CC}-16$ \\
\hline Viscosity of sludge, $\mathrm{Pa} \cdot \mathrm{s}^{b}$ & $0.095(9.5 \mathrm{cP})$ & $0.095(9.5 \mathrm{cP})$ & $0.095(9.5 \mathrm{cP})$ & $0.09(9.5 \mathrm{cP})$ \\
\hline Viscosity of grouts, $\mathrm{Pa} \cdot \mathrm{s}$ & 0.041 (41 cP) & $0.019(19 \mathrm{cP})$ & $0.031(31 \mathrm{cP})$ & $0.051(51 \mathrm{cP})$ \\
\hline Density, $\mathrm{g} / \mathrm{cm}^{3}$ & $1.51(12.60 \mathrm{lb} / \mathrm{gal})$ & $1.55(12.95 \mathrm{lb} / \mathrm{gal})$ & $1.55(12.051 \mathrm{~b} / \mathrm{gal})$ & $1.50(12.501 \mathrm{~b} / \mathrm{ga} 1)$ \\
\hline Phase separation, vol $\%$ & 1.0 & 6.0 & 0.9 & 1.6 \\
\hline$K^{\prime}$ & $9.07 \times 10^{-2}$ & $2.45 \times 10^{-3}$ & $9.99 \times 10^{-3}$ & $1.23 \times 10^{-1}$ \\
\hline$n^{\prime}$ & 0.24 & 0.70 & 0.55 & 0.23 \\
\hline Critical velocity, $\mathrm{m} / \mathrm{s}$ & $1.76(5.79 \mathrm{ft} / \mathrm{s})$ & $0.75(2.45 \mathrm{ft} / \mathrm{s})$ & $1.20(3.95 \mathrm{ft} / \mathrm{s})$ & $1.92(6.34 \mathrm{ft} / \mathrm{s})$ \\
\hline FLow rate, $\ell / s$ & $3.57(56.7 \mathrm{gal} / \mathrm{min})$ & $1.51(24.0 \mathrm{gal} / \mathrm{min})$ & $1.39(38.7 \mathrm{gal} / \mathrm{min})$ & $3.91(62.0 \mathrm{gal} / \mathrm{min})$ \\
\hline
\end{tabular}

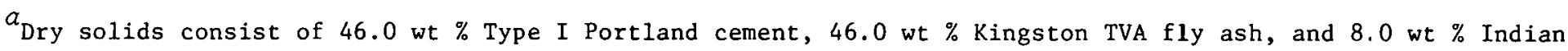
Red Pottery clay.

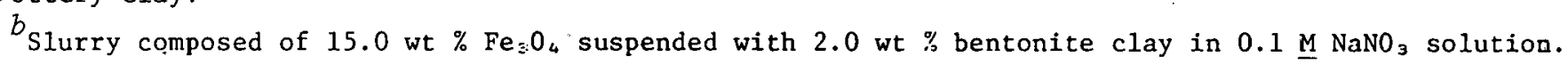


reduces the critical velocity and increases the density and flow behavior index $\left(n^{\prime}\right)$ but increases the phase separation. The inference here is that the grout becomes more Newtonian. However, the objectionable effect is that there is increased phase separation. The Q-Broxin, however, decreases the critical velocity and increases the density and flow behavior index without increasing the phase separation. Even though the grout containing CC-16 demonstrated an increase in viscosity, the pumping properties are essentially identical to the grout without the additive.

\section{CONCLUSIONS AND RECOMMENDATTUNS}

The rheograms presented in thie report were designed for field personnel to be used in determining the dry solids/slurry ratio for making suitable grouts from sludge-slurries of various viscosities. The grouts referenced to $719.0 \mathrm{~g} / \mathrm{l}$ exhibit critical velocities twice that of the reference grout when the calculations are based on a 5.08-cm-ID tube but are quite accurate when referenced to a $958-\mathrm{g} / \ell$ reference grout. Addition of dry solids in the field can be based solely on the viscosity of the slurry.

Bentonite is an effective suspender for mixed oxide particle slurries

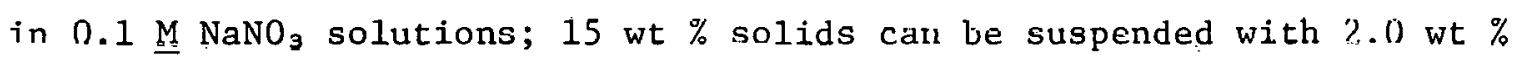
bentonite at a settling rate $\leq 5.0$ vo $1 \%$ in $24 \mathrm{~h}$.

Under rntrolled conditiuns, the viscosity of a bentonite slurry is a function of $\mathrm{pH}$. The slurry will thicken to a maximum viscosity at a $\mathrm{pH}$ of 11.2, but the actual viscosity achieved depends on shear rate and t.ime. The viscosity decreases for $\mathrm{pH}<11.2$, even with increased shear rate and time.

Chemical additives cau be used to control the flow properties of sludge-slurries and grouts. These chemicals should not be used unless necessary since they would add to the complexity of the grout and increase operating costs. 


\section{ACKNOWLEDGMENTS}

Appreciation is expressed to the following companies for furnishing materials used in this report:

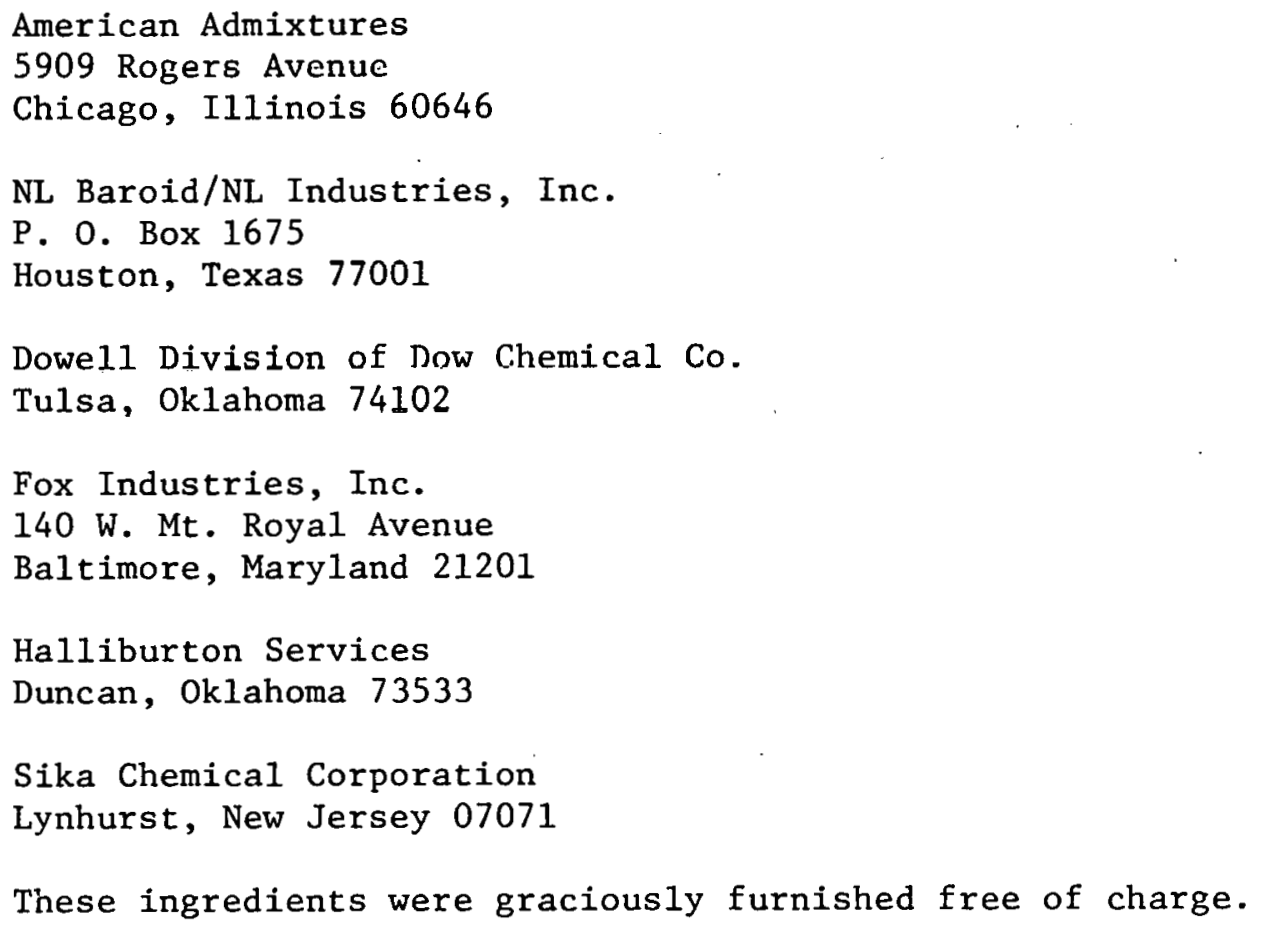

\section{REFERENCES}

1. W. delaguna, T. Tamura, H. O. Weeren, E. G. Struxness, W. C. McClain, and R. C. Sexton, Engineering Development of Hydraulic Fracturing as a Method for Permanent Disposal of Radioactive Waste, ORNI -4259 (August 1968).

2. J. G. Moore, H. W. Godbee, A. H. Kibbey, and D. S. Joy, Development of Cementitious Grouts for the Incorporation of Radioactive Wastes, Part I: Leach Studies, ORNL-4962 (April 1975).

3. R. H. Perry and C. H. Chilton, Chemical Engineer's Handbook, 5th ed., Sect. 5, McGraw-Hill, New York, 1973.

4. D. K. Smith, Cementing, Society of Petroleum Engineers of AIME, New York, 1976.

5. H. 0. Weeren, Shale Fracturing Injections at ORNL-1972 Series, ORNL/TM-4467 (June 1974). 
6. H. O. Weeren, Shale Fracturing Injections at ORNL-1975 Series, ORNL/TM-5545 (August 1976).

7. Halliburton Services, Ine., Technical Manual, Duncan, Okla., 1972.

8. R. R. Irani and C. F. Callis, Particle Size Measurement, Interpretation and Application, Wiley, New York, 1963.

9. Principles of Drizling Fluid Control, 12th ed., edited by a subcommittee of the API Southern District Study Committee on Drilling Fluids, published by Petroleum Extension Service, The University of Texas at Austin, in cooperation with the International Association of Drilling Contractors, Houston, Tex., 1978.

10. Fundomental Characteristics of Drilling Fluids, Vol. I., Sect. III, Baroid Petroleum Services Division NL Industries, Inc., Houston, Tex., 1978. 
ORNL/TM-7497

Dist. Category UC-70

\section{INTERNAL DISTRIBUTION}

1. W. C. Davis

2. G. J. Dixon

3. R. D. Ehrlich

4. H. W. Godbee

5. A. R. Godsey

6. G. D. Howell

7. R. E. Lampton

8. L. C. Lasher

9. A. L. Lotts

10. R. S. Lowrie

11-15. E. W. McDaniel

16. H. A. Mitchell

17. J. G. Moore
18. M. T. Morgan

19-23. E. Newman

24. G. E. Oswald

25. M. M. Osborne

26. G. C. Rogers

27. D. Richards

28. D. P. Stevens

29. H. O. Weeren

30. G. A. West

31. Document Reference Section

32-37. Laboratory Records

38. Laboratory Records - RC

39. ORNL Patent Section

40-42. Central Research Library

\section{EXTERNAL DISTRIBTUION}

43. Office of Assistant Manager, Energy Research and Development, DOE-ORO, P. O. BOX E, Oak Ridge, TN 37830

44. Director, Nuclear Research and Development Division, DOE-ORO, P. O. Box E, Oak Ridge, TN 37830

45. W. F. Bennett, Rocky Flats Area Office, P. O. Box 928, Golden, CO 80401

46. G. H. Daly, Chief, Technology Branch, Division of Waste Products, Office of Nuclear Waste Management, Mail Stop B-107, U. S.

Department of Energy, Washington DC 20545

47. J. E. Dieckhoner, Chief, Operations Branch, Division of Waste Products, Office of Nuclear Waste Management, U,S, Department. of Energy, Washington, DC 20545

48. E. W. Goldberg, Chief of Waste Management, Savannah River Operations Office, P. O. Box A, Aiken, SC 29801

49-50. D. E. Large, DOE-ORO, P. O. Box E, Oak Ridge, TN 37830

51. G. Levin, EG\&G Idaho, Inc., Box 1625, Idaho Falls, 83401

52. K. Y. Lowrey, Chief, Waste Management Branch, Albuquerque Operations office, P. 0. Box 5400, Albuquerque, NM 87115

53. G. Oertel, Director, Division of Waste Products, Office of Nuclear Waste Management, U.S. Department of Energy, Washington, DC 20545

54. J. W. Peel, Radioactive Waste Management, U.S. Department of Energy, Idaho Operations Office, 550 Second Street, Idaho Falls, ID 83401 
55. Car1 W. Scheffel, P.E. Vice-President, Fox Industries, Inc., 140 West Mount Royal Avenue, Baltimore, MD 21201

56. J. B. Whitsett, Chief of Radioactive Waste Management, U.S. Department of Energy, Idaho Operations Office, 550 Second Street, Idaho Falls, ID 83401

57-370. Given distribution as shown in TID-4500 under UC-70, Nuclear Waste Management 